\title{
INVENTORY ASSESSMENT METHODS IN TRADING AND MANUFACTURING COMPANIES: AN EMPIRICAL STUDY
}

\author{
Ardiani Ika Sulistyawati, Siti Farikah, Aprih Santoso, Sri Yuni Widowati \\ Fakultas Ekonomi Universitas Semarang \\ aprihsantoso@usm.ac.id
}

\begin{tabular}{l} 
INFO ARTIKEL \\
\hline Histori Artikel : \\
Tgl. Masuk : 16 Mei 2019 \\
Tgl. Diterima : 23 Agustus 2019 \\
Tersedia Online : 30 September 2019 \\
\hline Keywords: \\
inventory valuation method, \\
FIFO, average, variability of \\
inventory, company size, \\
intensity supplies
\end{tabular}

ABSTRAK/ABSTRACT

The purpose of the study was to determine the effect of the variability of inventory, company size, intensity inventory, accounting earnings variability, variability in cost of goods sold and the ownership structure of the inventory valuation method. Valuation method used is the First In First Out (FIFO) and average method. The object of this study is a trading and manufacturing company listed on the Stock Exchange from 2009-2014. There are 50 companies that meet the criteria, 10 companies using the FIFO method and 40 companies use the average method. Statistical analysis tools used in this study is a logistic regression with significance level of $5 \%$.

These results indicate the variability of inventory and company size significantly influence the selection method of inventory valuation. While the intensity of inventory, accounting earnings variability, variability in cost of goods sold and the ownership structure does not significantly influence the selection method of inventory valuation.

\section{PENDAHULUAN}

Persaingan dunia usaha di Indonesia sekarang ini telah mengalami kemajuan yang cukup pesat. Banyak perusahaanperusahaan baru yang didirikan sehingga menyebabkan persaingan yang semakin ketat. Perusahaanperusahaan yang bergerak baik di bidang jasa, manufaktur, maupun dagang saling bersaing untuk dapat bertahan dan menjadi yang terbaik. Untuk mencapai tujuan itu, setiap perusahaan berlomba-lomba berusaha memperbaiki kekurangan maupun kelemahan yang dimilikinya agar mampu bersaing dengan perusahaan lain.
Hambatan atau kendala dalam kegiatan produksi dapat terjadi karena beberapa hal, salah satunya adalah karena persediaan. Ketika terjadi kendala dalam persediaan misalnya keterlambatan persediaan, maka proses produksi secara otomatis juga akan terhambat yang nantinya akan berdampak pula dalam hal kemampuan memperoleh laba. Persediaan (Inventory), merupakan aktiva perusahaan yang menempati posisi yang cukup penting dalam suatu perusahaan, baik itu perusahaan dagang maupun perusahaan industri (manufaktur), apalagi perusahaan yang bergerak dibidang konstruksi, hampir $50 \%$ dana perusahaan akan 
tertanam dalam persediaan yaitu untuk membeli bahan-bahan bangunan .

Perhitungan persediaan pun dapat mempengaruhi neraca maupun laporan laba rugi. Apabila terjadi kesalahan dalam perhitungan persediaan bisa mengakibatkan kesalahan dalam saldo persediaan akhir, aktiva lancar, dan total aktiva dalam neraca, sebab perhitungan persediaan dijadikan dasar dalam membuat jurnal penyesuaian untuk mencatat penciutan persediaan. Hal lain yang dapat terjadi dalam kesalahan perhitungan persediaan adalah timbulnya kekeliruan dalam penyajian harga pokok penjualan, laba kotor, dan laba bersih dalam laporan keuangan, Warren dkk (dalam Ulfa, 2013).

Berdasarkan PSAK 14 (1994), pemilihan metode akuntansi yang diakui di Indonesia ada tiga. Metode akuntansi tersebut yaitu metode Masuk Pertama Keluar Pertama (MPKP) atau yang sering disebut dengan First In First Out (FIFO), Masuk Terakhir Keluar Pertama (MTKP) atau yang sering disebut dengan Last In First Out (LIFO), dan metode rata-rata atau weighted average. Akan tetapi sekarang ini terdapat revisi yang membedakan metode akuntansi persediaan atau dengan kata lain telah dilakukannya revisi PSAK 14 (revisi 2008). Jika sebelum revisi terdapat 3 metode akuntansi persediaan yang diakui, maka setelah adanya revisi, metode akuntansi yang diakui hanya FIFO dan weighted average.

Beberapa penelitian yang terkait dengan persediaan telah dilakukan sebelumnya dengan obyek perusahaan yang terdaftar di Bursa Efek Indonesia. Penelitian yang dilakukan oleh Herlin (2011), pada penelitian ini menggunakan variabel independen ukuran perusahaan, intensitas persediaan, variabilitas laba akuntansi dan variabilitas harga pokok penjualan. Dimana dari ke empat variabel tersebut tidak signifikan dengan pemilihan metode penilaian persediaan.

Penelitian selanjutnya dilakukan oleh Srimonah (2011) dengan menggunakan variabel variabilitas persediaan, ukuran perusahaan, financial leverage, rasio lancer dan Struktur kepemilikan. Variabel ukuran perusahaan perusahaan menunjukan hasil yang signifikan, sedangkan tiga variabel lainnya menunjukan hasil yang tidak signifikan terhadap pemilihan metode penilaian persediaan.

Selanjutnya Kukuh (2012) menggunakan variabel variabilitas persediaan, ukuran perusahaan, intensitas persediaan dengan hasil signifikan dan margin laba kotor, variabilitas harga pokok penjualan, financial leverage, rasio lancer menunjukan hasil yang tidak signifikan terhadap pemilihan metode penilaian persediaan. Penelitian berikutnya dilakukan oleh Seyla (2013) dengan menggunakan dua variabel yaitu ukuran perusahaan dan margin laba kotor. Dimana ukuran perusahaan menunjukan hasil yang signifikan sedangkan margin laba kotor menunjukan hasil yang tidak signifikan terhadap pemilihan metode penilaian persediaan.

Kemudian Restu (2013) dengan menggunakan variabel ukuran perusahaan, intensitas persediaan dan margin laba kotor. Ketiga variabel tersebut menunjukan hasil yang tidak signifikan terhadap pemilihan metode penilaian persediaan. Penelitian selanjutnya dilakukan oleh Thresya (2013) dengan menggunakan variabel variabilitas persediaan, ukuran perusahaan, variabilitas harga pokok penjualan, financial leverage dan laba sebelum pajak. Variabel variabilitas 
persediaan dan variabilitas harga pokok penjualan menunjukan hasil yang signifikan, sedangkan tiga variabel ukuran perusahaan, financial leverage dan rasio lancer menunjukan hasil yang tidak signifikan.

Berikutnya Sangadah (2014) dengan menggunakan variabel variabilitas persediaan, ukuran perusahaan, intensitas persediaan, margin laba kotor, variabilitas laba akuntansi, variabilitas harga pokok penjualan, financial leverage dan likuiditas. Dari ke delapan variabel tersebut hanya satu variabel yang menunjukan hasil yang signifikan yaitu variabilitas persediaan. Sedangkan tujuh variabel lain menunjukan hasil yang tidak signifikan terhadap pemilihan metode penilaian persediaan.

Selanjutnya Brian (2014) dengan menggunakan variabel variabilitas persediaan, ukuran perusahaan, intensitas persediaan, variabilitas laba akuntansi dan Struktur kepemilikan. Variabel variabilitas persediaan, ukuran perusahaan dan menunjukan hasil yang signifikan, sedangkan dua vaiabel lain menunjukan hasil yang tidak signifikan terhadap pemilihan metode penilaian persediaan.

\section{KERANGKA TEORITIS DAN PENGEMBANGAN HIPOTESIS}

\section{Teori Akuntansi Positif (Accounting Positive Theory)}

Teori akuntansi positif merupakan teori yang berusaha menjelaskan dan memprediksi fenomena tertentu di masa mendatang. Ada tiga hipotesis yang dikemukakan oleh Watss dan Zimmerman (dalam Ulfa, 2013), yang mewakili tindakan manajer untuk memilih metode akuntansi, yaitu bonus plan hypotesis, debt covenant hypotesis, dan political cost hypotesis.
Dari ketiga hipotesis tersebut debt covenant hypotesis dan political cost hypotesis yang berhubungan dengan penelitian ini.

\section{Debt Covenant Hypothesis}

Debt covenant hypothesis atau juga disebut debt/equity hypothesis merupakan hipotesis yang berkaitan dengan syarat-syarat yang harus dipenuhi perusahaan di dalam perjanjian hutang (debt covenant). Hipotesis ini menyatakan bahwa perusahaan dengan debt covenant ratio yang tinggi, akan cenderung menggunakan metode akuntansi yang dapat meningkatkan pendapatan. Tingginya debt covenant ratio akan menimbulkan biaya dan dapat menghambat kinerja manajemen, maka dengan menjalankan kebijakan untuk memilih metode akuntansi yang dapat meningkatkan pendapatan, manajer dapat menghindari atau menunda timbulnya biaya tersebut.

2. Political Cost Hypohtesis

Political cost hypothesis menyatakan bahwa perusahaan besar cenderung menggunakan metode akuntansi yang dapat mengurangi laba dibandingkan perusahaan kecil, karena ukuran perusahaan merupakan sesuatu yang paling diperhatikan dalam hal ini. Hipotesis ini juga memaparkan semakin besar biaya politis yang dihadapi perusahaan maka semakin besar pula keinginan perusahaan untuk menggunakan pilihan akuntansi yang dapat mengurangi laba, sebab perusahaan dengan tingkat laba yang tinggi dinilai akan mendapat perhatian yang luas dari konsumen dan media yang nantinya juga akan menarik perhatian pemerintah dan regulator sehingga menyebabkan terjadinya biaya politis, diantaranya muncul intervensi pemerintah, pengenaan pajak yang lebih tinggi, dan berbagai tuntutan lain 
yang dapat meningkatkan biaya polits. Berdasarkan teori ini, manajer lebih memilih untuk menggunakan metode akuntansi yang dapat meminimalkan pendapatan.

\section{Hipotesis Ricardian (Ricardian Hypohtesis)}

Lee dan Heish (dalam Ulfa, 2013) mengungkapkan, bahwa faktor yang paling mempengaruhi perusahaan adalah peraturan perpajakan, dimana tujuan yang ingin dicapai oleh manajemen adalah memaksimalkan nilai perusahaan dengan cara meminimalkan biaya pajak namun tetap respek terhadap kendala hukum. Hipotesis ini disebut hipotesis pajak atau ricardian hypothesis. Kaitan hipotesis ini dengan metode penilaian persediaan,membuat manajer perlu mempertimbangkan pengaruh pajak saat memutuskan memilih metode penilaian persediaan yang akan digunakan.

\section{Metode Penilaian Persediaan}

Pemilihan metode penilaian persediaan untuk pelaporan keuangan di Indonesia diatur dalam Pernyataan Standar Akuntansi Keuangan (PSAK) 14. Untuk memenuhi kebijakan fiskal, berdasarkan PSAK 14 (Revisi 2008) dan Undang-Undang Pajak Penghasilan No. 36 Tahun 2008, pihak perusahaan hanya diperbolehkan untuk menggunakan metode FIFO dan metode rata-rata. Hal ini berarti metode LIFO sudah tidak diperbolehkan untukdigunakan dan perusahaan diberi kebebasan untuk memilih metode persediaan mana yang akan digunakan dari dua metode tersebut. Apabila suatu perusahaan dalam laporan keuangannya menggunakan metode LIFO, maka untuk tujuan fiskal harus membuat kembali dengan metode FIFO atau rata-rata.

\section{Variabilitas Persediaan}

Variabilitas persediaan menggambarkan variasi dari nilai persediaan suatu perusahaan. Istilah variabilitas persediaan ini telah digunakan oleh beberapa peneliti terdahulu yang mencoba meneliti variabel varibilitas persediaan. Apabila suatu perusahaan mempunyai nilai persediaan yang relatif stabil maka pengaruhnya pada variasi laba akan kecil, sedangkan pada perusahaan yang mempunyai nilai persediaan yang bervariasi pada setiap tahun maka laba yang dihasilkan juga akan bervariasi.

\section{Ukuran Perusahaan}

Ukuran perusahaan dapat mempengaruhi pemilihan metode akuntansi persediaan. Semakin besar ukuran perusahaan, maka perusahaan dapat memilih metode akuntansi yang sesuai dengan keadaan yang terjadi pada saat itu karena manajer memiliki keahlian dan spesialisasi untuk memilih metode akuntansi persediaan yang tepat sesuai keadaan yang terjadi maupun tujuan perusahaan.

\section{Intensitas Persediaan}

Menurut Susanto (2015)

Intensitas persediaan (Inventory Turnover) merupakan suatu ukuran yangdigunakan untukmengevaluasi apakah tingkat persediaan tepat, jika dibandingkandengan volume usaha.Turnover ini menunjukkan berapa kali jumlah persediaanbarang dagangan diganti atau dijual dalam satu tahun.

\section{Variabilitas Laba Akuntansi}

Variabilitas laba akuntansi dipengaruhi oleh factorinternal 
perusahaan maupun eksternal perusahaan. Secarainternal, variabilitas ini dibentuk olehkebijakan perusahaan, baik yang berkaitan dengan teknik operasionalperusahaan maupunkebijakan akuntansi perusahaan. Adapun secara eksternal, kondisi ekonomi, baik berupa inflasimaupun kebijakan pemerintah juga berdampak terhadap variabilitas laba akuntansi. Ronen danSadan(dalam Herlin, 2011) memberikan penjelasan alternatif bahwa smootingincome memfasilitasimanajer-manajer untuk memprediksi secara lebih baik aliran kas masadepan yang didasarkan pada nilai perusahaan.

\section{Variabilitas Harga Pokok Penjualan} Harga pokok penjualan merupakan dasar yang ditentukan perusahaan dalammenjual produknya dan mendapatkan laba yang diinginkan. Menurut Zaki Baridwan (dalam Susanto, 2015), menyatakan bahwa harga pokok penjualan adalah nilaiyang ditetapkan oleh perusahaan terhadap barang dan jasa dalam hubungannya penetapan harga yang didasarkan pada besarnya biaya produksiditambahkandengan

keuntungan yang diharapkan.

\section{Struktur kepemilikan}

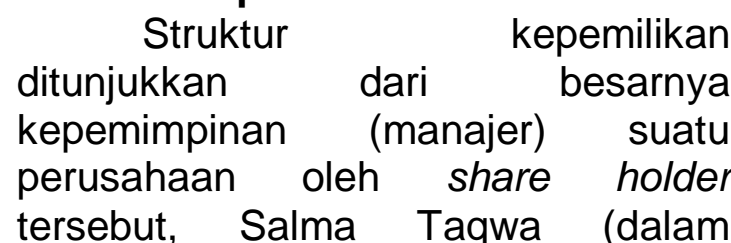
Srimonah, 2011). Sehubungan dengan pemilihan metode akuntansi persediaan, antara manajer dengan pemilik akan timbul konflik kepentingan. Masing-masing pihak, yaitu manajerakan berusaha memaksimalkan kesejahteraannya masing-masing. Salma Taqwa (dalam Srimonah, 2011) menjelaskan bila manajer memiliki persentase kepemilikan saham yang kecil pada suatu perusahaan maka manajer mempunyai kecenderungan memilih metode FIFO. Sebaliknya bila manajer memiliki saham dengan persentase yang relatif besar, maka manajer akan memilih metode rata-rata.

\section{Hubungan Logis Antar Variabel dan Perumusan Hipotesis \\ Hubungan Variabilitas Persediaan dengan Pemilihan Metode Akuntansi Persediaan}

Variabilitas persediaan merupakan nilai persediaan. Semakin kecil variasi nilai persediaan maka variasi terhadap labanya juga akan kecil. Variabilitas persediaan dapat mempengaruhi pemilihan metode penilaian persediaan karena pemilihan metode persediaan yang berbeda akan menghasilkan nilai persediaan yang berbeda. Ketika terjadi inflasi, penggunaan metode FIFO akan menghasilkan variasi persediaan yang tinggi yang akan berdampak pada naiknya laba. Sebaliknya, penggunaan metode rata-rata ketika terjadi inflasi tidak terlalu menyebabkan variasi persediaan yang terlalu tinggi sehingga labanya juga akan lebih rendah daripada menggunakan metode FIFO. $\mathrm{H} 1$ : Variabilitas persediaan berpengaruh terhadap metode penilaian persediaan

\section{Hubungan Ukuran Perusahaan dengan Pemilihan Metode Akuntansi Persediaan}

Biaya politik (political cost) dari pemerintah yang berupa ancaman regulasi dan nasionalisasi lebih besar akan dirasakan oleh perusahaan besar karena pemerintah lebih mudah mengawasi perusahaan melalui laporan keuangan yang ada (Taqwa, 2001). Apabila perusahaan melaporkan laba yang besar maka 
akan dicurigai melakukan monopoli Horgn-Ching Kuo (dalam Kukuh, 2012). Karena beberapa alasan tersebut, ukuran perusahaan akan mempengaruhi pemilihan metode penilaian persediaan. Semakin besar ukuran perusahaan, maka perusahaan akan memilih metode rata-rata yang dapat menurunkan laba sehingga mereka bisa melakukan tax saving dan menghindari dugaan melakukan monopoli serta menghindarkan perusahaan dari biaya politik. Sedangkan untuk perusahaan kecil, mereka akan memilih metode yang dapat menaikkan laba yaitu metode FIFO untuk dapat memperoleh pinjaman dari bank karena bank menilai kinerja perusahaan melalui laba yang dihasilkan.

$\mathrm{H} 2$ : Ukuran perusahaan berpengaruh terhadap metode penilaian persediaan

\section{Hubungan Intensitas Persediaan dengan Pemilihan Metode} Akuntansi Persediaan

Intensitas persediaan atau rasio perputaran persediaan rnenunjukkan keefektifan dan keefisienan perusahaan untuk mengatur investasinya dalam persediaan yang dihubungkan dengan berapa kali persediaan perusahaan itu diputar selarna satu periode tertentu. Intensitas persediaan yang tinggi rnenunjukkan jurnlah penjualan pada perusahaan tersebut tinggi dan menghasilkan laba yang tinggi. Ketika persediaan tinggi, maka manajer akan memilih metode rata-rata agar persediaannya menjadi lebih kecil daripada ketika menggunakan metode FIFO. Hal ini dilakukan agar kinerja manajer dalam mengelola persediaan dianggap baik oleh perusahaan karena semakin rendah persediaan, maka semakin efisien pula pengelolaan persediaannya.

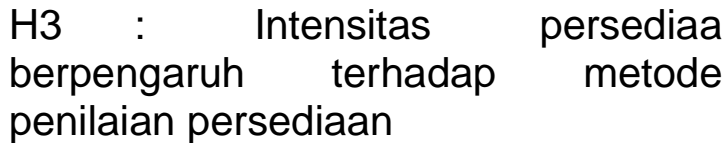

Hubungan Variabilitas Laba Akuntansi dengan Pemilihan Metode Akuntansi Persediaan

Variabilitas laba akuntansi akan mempengaruhi pemilihan metode penilaian persediaan. Metode rata-rata akan memberikan laba akuntansi yang cenderung lebih stabil dan lebih kecil dibandingkan dengan metode FIFO. Variabilitas laba akuntansi digunakan sebagai proksi untuk volatilitas operasional perusahaan. Volatilitas operasional tergantung atas sifat pasar output, teknologi produksi, dan lingkungan ekonomi umum, Lee dan Hsieh (dalam Brian, 2014). Selain itu variabilitas laba akuntansi juga dipengaruhi oleh faktor internal maupun eksternal perusahaan. Secara internal dipengaruhi oleh teknik operasional maupun kebijakan akuntansi yang dimiliki perusahaan.

H4 : Variabilitas laba akuntansi berpengaruh terhadap metode penilaian persediaan

\section{Hubungan Variabilitas Harga Pokok Penjualan dengan Pemilihan Metode Akuntansi Persediaan}

Bila harga pokok ditentukan dengan metode yang berbeda, maka akan mempunyai pengaruh yang substansial terhadap laba periode, Gibson (dalam Kukuh, 2012). Melihat dari berbagai pendapat yang ada, dapat disimpulkan bahwa variabilitas harga pokok penjualan mempengaruhi pemilihan metode akuntansi persediaan. Ketika terjadi inflasi, maka penggunaan metode FIFO akan memberikan laba yang lebih besar terhadap perusahaan. Pengaruh perubahan harga-harga akan tercermin baik pada persediaan 
ataupun pada harga pokok penjualan Tuanakotta, (dalam Kukuh, 2012).
H6 : Struktur kepemilikan berpengaruh terhadap metode penilaian persediaan

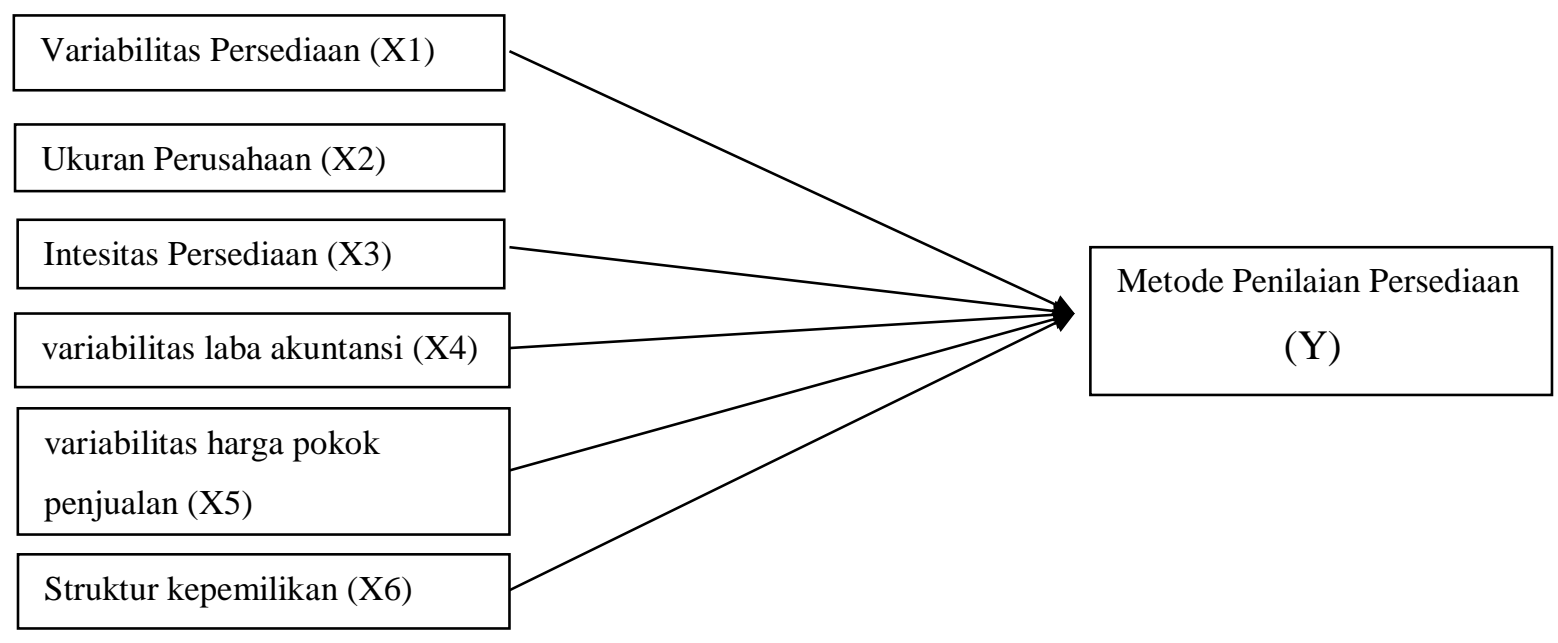

H5 : Variabilitas harga pokok penjualan berpengaruh terhadap metode penilaian persediaan

\section{Hubungan Struktur kepemilikan dengan Pemilihan Metode Akuntansi Persediaan}

Struktur kepemilikan dalam perusahaan sering menimbulkan adanya konflik kepentingan antara manajemen perusahaan dengan pemegang saham atau biasa disebut dengan agency theory. Pemilihan metode persediaan merupakan suatu contoh yang baik untuk menjelaskan bagaimana konflik terjadi antara manajer dan pemegang saham. Metode FIFO adalah metode yang disukai manajer, sebab metode ini pada dasarnya dapat meningkatkan laba perusahaan. Jika hal ini terjadi, maka akan timbul konflik antara manajer dengan pemegang saham. Ada anggapan bahwa semakin tinggi tax liability, maka akan semakin rendah harga saham. Dengan alasan tersebut diasumsikan pemegang saham berusaha agar manajer memilih suatu metode penilaian persediaan yang dapat meminimumkan pajak pendapatan.

\section{Kerangka Pemikiran}

Berdasarkan

penjelasan tersebut, kerangka pemikiran yang menggambarkan hubungan antara variabel variabilitas persediaan, ukuran perusahaan, intesitas persediaan, variabilitas laba akuntansi, variabilitas harga pokok penjualan dan Struktur kepemilikan adalah sebagai berikut :

\section{METODE PENELITIAN}

\section{Variabel Penelitian dan Definisi Operasional}

Variabel terikat dalam penelitian ini adalah metode penilaian persediaan. Metode penilaian persediaan diukur dengan variabel dummy, dimana kategori 1 untuk perusahaan yang menggunakan metode FIFO dan kategori 0 untuk perusahaan yang menggunakan metode rata-rata. Sedangkan variabel bebas dalam penelitian ini adalah variabilitas persediaan, ukuran perusahaan, intesitas persediaan, variabilitas laba akuntansi, variabilitas harga pokok penjualan dan struktur kepemilikan. 
1. Variabilitas persediaan merupakan variasi dari nilai persediaan pada suatu perusahaan.Variabilitas persediaan diukur berdasarkan koefisien variasi jumlah persediaan akhir yaitu standar deviasi/mean selama enam tahun. Skala yang digunakan adalah rasio, satuan yang digunakan berupa presentase.Rasio ini dapat dihitung dengan rumus sebagai berikut :

Variabilitas persediaan = Standardeviasipersediaanakhir Rata-ratapersediaanakhir

2. Ukuran perusahaan adalah ratarata total penjualan bersih untuk tahun yang bersangkutan sampai beberapa tahun.Ukuran perusahaan merupakan proksi volatilitas operasional dan inventory cotrolability yang seharusnya dalam skala ekonomis besarnya perusahaan menunjukkan pencapaian operasi lancar dan pengendalian persediaan (Mukhlasin, 2002).Rasio ini dapat dihitung dengan rumus sebagai berikut :

Ukuran Perusahaan= Totalasettahunpenelitian Totaltahunpenelitian

3. Intensitas persediaan (Inventory Turnover) merupakan suatu ukuran yang digunakan untuk mengevaluasi apakah tingkat persediaan tepat, jika dibandingkan dengan volume usaha.Turnover ini menunjukkan berapa kali jumlah persediaan barang dagangan diganti atau dijual dalam satu tahun.Rasio ini dapat dihitung dengan rumus sebagai berikut :

\footnotetext{
Intensitas Persediaan= Hargapokokpenjualan

(Persediaanawal+Persediaanakhir $) / 2$
}

4. Variabilitas laba akuntansi adalah variasi laba bersih perusahaan sebelum dipotong pajak. Laba akuntansi merupakan laba yang tercantum dalam laba rugi tahunan yaitu laba sebelum pajak. Rasio ini dapat dihitung dengan rumus sebagai berikut :

Variabilitas Laba Akt = Standardeviasilabasebelumpajak

Rata-ratalabaakuntansisebelumpajak

5. Variabilitas harga pokok penjualan adalah variasi dari nilai yang ditetapkan oleh perusahaan terhadap barang dan jasa dalam hubungannya penetapan harga yang didasarkan pada besarnya biaya produksi ditambahkan dengan keuntungan yang diharapkan.Rasio ini dapat dihitung dengan rumus sebagai berikut :

\section{Variabilitas HPP = Standardeviasihargapokokpenjualan Hargapokokpenjualanrata-rata}

6. Struktur kepemilikan adalah struktur kepemilikan saham, yaitu perbandingan jumlah saham yang dimiliki oleh orang dalam (insiders) dengan saham yang dimiliki oleh investor. Struktur Kepemilikan menggunakan variabel dummy, dengan pengukuran 1 (satu) jika manajer memiliki saham pada perusahaan sedangkan dan 0 (nol) jika manajer tidak memiliki saham pada perusahaan.

\section{Populasi dan Sampel}

Populasi dalam penelitian ini adalah perusahaan dagang dan manufaktur yang telah terdaftar di Bursa Efek Indonesia pada tahun 2009 sampai 2014. Metode pengambilan sampel dalam penelitian ini menggunakan metode purpose 
sampling. Adapun kriteria-kriteria yang digunakan untuk pemilihan sampel adalah sebagai berikut :

a. Melaporkan laporan keuangan perusahaan secara berturut-turut pada tahun 2009-2014

b. Menggunakan satu metode penilaian persediaan

c. Menggunakan metode penilaian persediaan yang konsisten selama periode pengamatan

d. Perusahaan tidak mengalami delisting selama tahun pengamatan

e. Hanya yang dinyatakan dalam rupiah

\section{Jenis Data, Sumber Data, dan} Metode Pengumpulan Data

Jenis data yang digunakan dalam penelitian ini adalah data sekunder. Data yang digunakan dalam penelitian ini adalah data sekunder yang diperoleh dari website Bursa Efek Indonesia (BEI) yaitu www.idx.co.id. Data berupa laporan keuangan perusahaan periode 2009 sampai 2014. Metode pengumpulan data yang digunakan dalam penelitian ini adalah metode dokumentasi.

\section{Metode Analisis}

Analisis yang digunakan dalam penelitian ini adalah modelregresi logistik. Ghozali (2012) menjelaskan bahwa metode ini cocok digunakan untuk penelitian yang variabel dependennya mengunakan variabel non-metrik (nominal) sementara variabel independennya menggunakan variabel metrik dan non-metrik. Variabel independen dalam penelitian ini yang merupakan variabel metrik adalah profitabilitas, solvabilitas, ukuran perusahaan, leverage, dan kepemilikan institusional. Sedangkan variabel yang menggunakan variabel non-metrik (nominal) adalah kepemilikan manajerial. Metode analisis yang digunakan dalam penelitian ini adalah sebagai berikut :

1. Statistik Deskriptif

Statistik deskriptif memberikan gambaran atau deskripsi suatu data yang dilihat dari nilai rata-rata (mean), standar deviasi, varian, maksimum, minimum, sum, range, kurtoris dan skewness (kemencengan distribusi) (Ghozali, 2012).

2. Analisis Pengujian Regresi Logistik Menilai Kelayakan Model Analisis pertama yang dilakukan adalah menilai kelayakan model regresi logistik yang akan digunakan. Menilai kelayakan model regresi menggunakan Hosmer and Lemeshow's Goodness OfFit Test. Hosmer and Lemeshow's Goodness Of Fit Test Kriteria penentuan data empiris sesuai dengan model atau tidak yaitu (Ghozali, 2012) :

Jika nilai Hosmer and Lemeshow's Goodness Of Fit Test Statistic sama dengan atau kurang dari 0,05 maka hipotesis nol ditolak yang berarti ada perbedaan signifikan antara model dengan nilai observasinya sehingga goodness fit model tidak baik karena model tidak dapat memprediksi nilai observasinya.

Jika nilai statistik Hosmer and Lemeshow Godness Of Fit lebih besar dari 0,05 maka hipotesis nol tidak dapat ditolak dan berarti model mampu memprediksi nilai observasinya atau dikatakan model dapat diterima karena cocok dengan data observasinya.

a. Menilai Keseluruhan Model/

b. Model Fit)

Langkah selanjutnya adalah menguji keseluruhan model regresi (Overall Model Fit). Pertama dengan melihat angka -2 LogLikelihood (LL) pada (block Number $=0$ ) dan angka -2 Log Likelihood pada block Number $=1$, jika terjadi penurunan angka -2 Log Likelihood (block Number $=0$ - block Number = 1) maka menunjukkan model regresi kedua lebih baik 
daripada regresi model pertama, yang artinya model fit terhadap data (Ghozali, 2012).

Untuk menjelaskan variabilitas variabel dependen yang dapat dijelaskan oleh variabilitas variabel independen digunakan Nagelkerke's R square yang berkisar antara 0-1. Nagelkerke's R square merupakan modifikasi dari koefisien Cox dan Snell untuk memastikan bahwa nilainya bervariasi dari 0 (nol) sampai 1 (satu). Hal ini dilakukan dengan cara membagi nilai Cox dan Snell's $\mathrm{R}^{2}$ dengan maksimumnya. Nilai Nagelkerke's $R$ square dapat diinterpretasikan seperti nilai $R^{2}$ pada multiple regression (Ghozali, 2012).

\section{Menguji Koefisien Regresi}

Pengujian koefisien regresi dilakukan untuk menguji seberapa jauh semua variabel bebas yang dimasukan dalam model mempunyai pengaruh terhadap variabel terikat. Model regresi logistik yang digunakan untuk menguji hipotesis sebagai berikut :

$$
\begin{aligned}
& \mathrm{Y}=\mathrm{a}+\mathrm{b}_{1} \mathrm{VP}+\mathrm{b}_{2} \mathrm{UP}+\mathrm{b}_{3} \mathrm{IP}+ \\
& \mathrm{b}_{4} \mathrm{VLA}+\mathrm{b}_{5} \mathrm{HPP}+\mathrm{b}_{6} \mathrm{SK}+\mathrm{e} \\
& \text { Keterangan : } \\
& \mathrm{Y}=\text { Pemilihan metode } \\
& \text { persediaan } \\
& \mathrm{a}=\text { konstanta } \\
& \text { VP }=\text { variabilitas persediaan } \\
& \text { UP }=\text { ukuran perusahaan } \\
& \text { IP }=\text { intesitas persediaan } \\
& \text { VLA }=\text { variabilitas laba } \\
& \text { akuntansi } \\
& \text { HPP }=\text { harga pokok penjualan } \\
& \text { SK }=\text { struktur kepemilikan } \\
& \text { b1,2,..6 }=\text { koefisien regresi } \\
& \mathrm{e}=\text { error }
\end{aligned}
$$

Menguji Hipotesis

Koefisien regresi ini diuji untuk mengetahui seberapa besar pengaruh dari masing-masing variabel bebas terhadap variabel terikat. Koefisien regresi dapat ditentukan dengan menggunakan wald statistic dan nilai probabilitas (sig) dibandingkan dengan a. Cara menentukan penolakan atau penerimaan Ho didasarkan pada tingkat signifikan (a ) 5\% dengan kriteria sebagai berikut :

Apabila

asymptotic significanse $>$ a, maka Ho diterima. Hal ini berarti $\mathrm{Ha}$ ditolak atau hipotesis yang menyatakan variabel bebas berpengaruh terhadap variabel terikat ditolak.

Apabila

asymptotic significanse $>$ a, maka Ho diterima. Hal ini berarti $\mathrm{Ha}$ ditolak atau hipotesis yang menyatakan variabel bebas

\begin{tabular}{|c|c|c|}
\hline No & Keterangan & \begin{tabular}{|l} 
Jumlah \\
Perusahaan
\end{tabular} \\
\hline 1. & \begin{tabular}{|lr} 
Perusahaan dagang dan \\
manufaktur & yang \\
mempublikasikan laporan \\
keuangan tahun & 2009 \\
2014 &
\end{tabular} & 115 \\
\hline 2. & $\begin{array}{l}\text { Menggunakan lebih dari } \\
\text { satu metode penilaian } \\
\text { persediaan }\end{array}$ & $i(28)$ \\
\hline 3. & $\begin{array}{l}\text { Perusahaan yang } \\
\text { menggunakan kurs dollar }\end{array}$ & $(20)$ \\
\hline 4. & \begin{tabular}{|lr} 
Perusahaan & yang tidak \\
konsisten & menerapkan \\
metode & penilaian \\
persediaan &
\end{tabular} & (17) \\
\hline 5. & $\mid \begin{array}{l}\text { Perusahaan } \\
\text { memenuhi kriteria sampel }\end{array}$ & \\
\hline
\end{tabular}
berpengaruh terhadap variabel terikat ditolak.

\section{HASIL DAN PEMBAHASAN}

terdaftar di Bursa Efek Indonesia periode 2009 sampai dengan 2014. Jumlah sampel yang diperoleh dari populasi yang ada sebanyak 50 perusahaan yang terdiri dari 2 kelompok, yaitu yang menggunakan metode rata-rata dan metode FIFO. Rincian selengkapnya sebagai berikut:

\section{Tabel 1}

Prosedur Pemilihan Sampel 


\begin{tabular}{|l|l|l|}
\hline $\begin{array}{l}\text { Metode FIFO } \\
\text { Metode Rata-rata }\end{array}$ & 40 \\
\hline
\end{tabular}

\section{Statistik Deskriptif}

Tabel 2

Statistik Deskriptif Variabilitas Persediaan

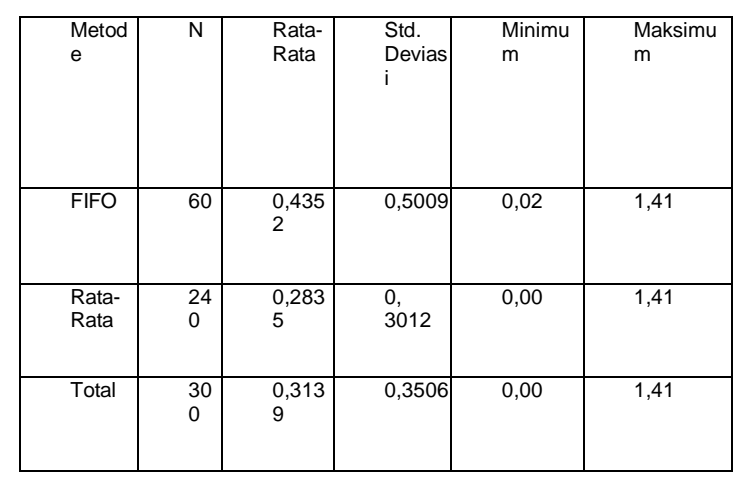

Tabel $\quad 4.4 \quad$ menunjukkan gambaran variabel variabilitas persediaan selama tahun 2009-2014 diperoleh rata-rata untuk perusahaan yang menggunakan metode FIFO sebesar 0,4352 sedangkan untuk kelompok perusahaan yang menggunakan metode rata-rata diperoleh rata-rata sebesar 0,2835 . Hal ini berarti bahwa variabilitas persediaan pada perusahaan yang menggunakan metode FIFO menunjukkan hasil yang lebih besar dibanding pada perusahaan yang menggunakan metode rata-rata.

\section{Tabel 3}

Statistik Deskriptif Ukuran

Perusahaan (dalam juta rupiah)
Sumber : Data sekunder yang diolah

Tabel 4.4 menunjukkan gambaran variabel ukuran perusahaan selama tahun 2009-2014 diperoleh rata-rata untuk perusahaan yang menggunakan metode FIFO sebesar 193.246,97 sedangkan untuk kelompok perusahaan yang menggunakan metode rata-rata diperoleh rata-rata sebesar 929.023,25. Hal ini berarti bahwa ukuran perusahaan yang menggunakan metode rata-rata menunjukkan aset yang lebih besar dibanding pada perusahaan yang menggunakan metode FIFO.

Tabel 4

Statistik Deskriptif Intensitas Persediaan

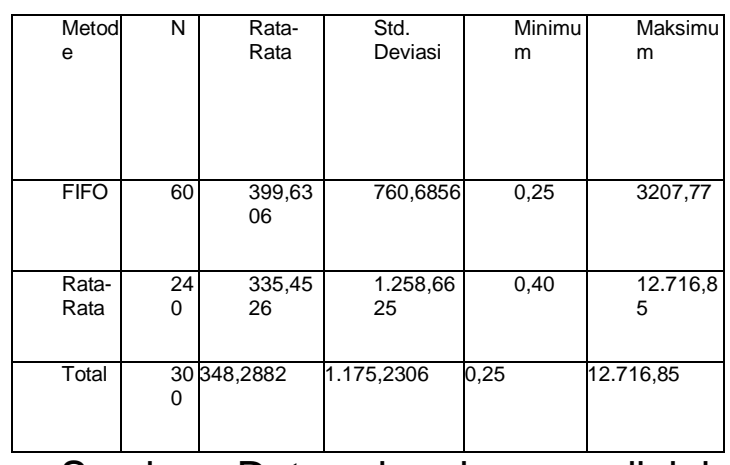

Sumber : Data sekunder yang diolah

Tabel 4.6 menunjukkan gambaran variabel intensitas persediaan selama tahun 2009-2014 diperoleh rata-rata untuk perusahaan yang menggunakan metode FIFO diperoleh sebesar 399,6306 sedangkan untuk kelompok perusahaan yang menggunakan metode rata-rata diperoleh rata-rata

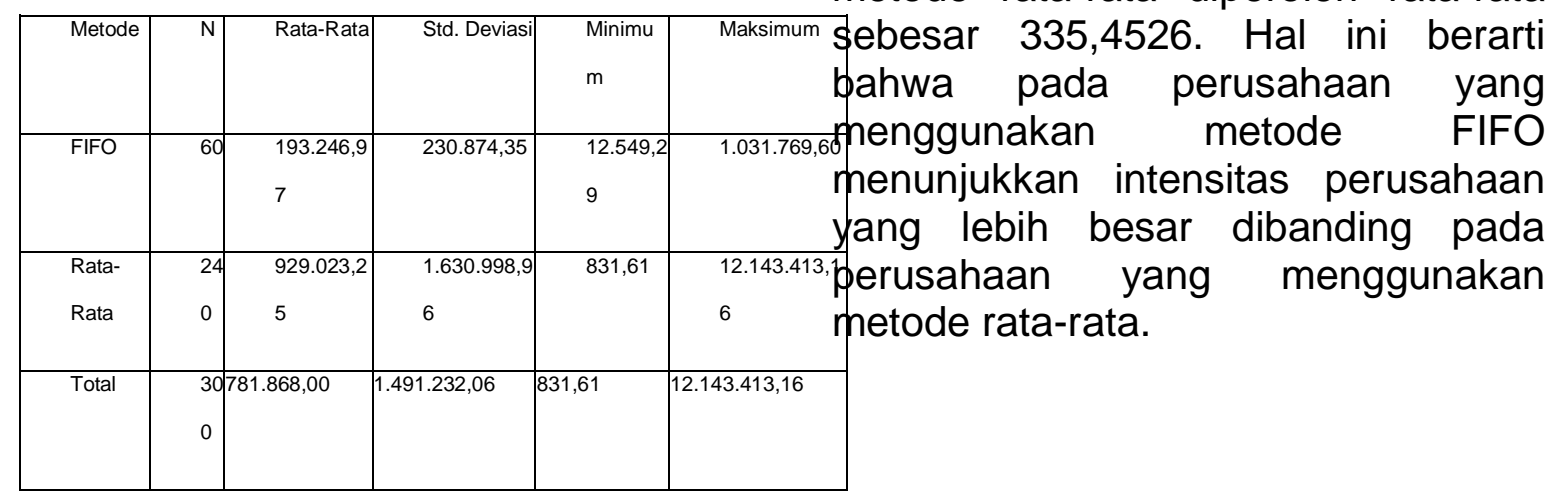


Tabel 5

Statistik Deskriptif Variabilitas Laba Akuntansi

\begin{tabular}{|c|r|r|r|r|r|}
\hline Metode & N & Rata- & Std. & Minimum & Maksimu \\
& & Rata & Deviasi & & \\
& & & & & \\
\hline FIFO & 60 & 17,4212 & 156,9785 & $-135,66$ & $1.205,43$ \\
& & & & & \\
\hline Rata- & 240 & 0,3960 & 3,0845 & $-24,95$ & 29,91 \\
Rata & & & & & \\
\hline Total & 300 & 3,8010 & 70,1189 & $-135,66$ & $1.205,43$ \\
& & & & & \\
\hline
\end{tabular}

Sumber : Data sekunder yang diolah

Tabel 4.7 menunjukkan gambaran variabel variabilitas laba akuntansi selama tahun 2009-2014 diperoleh rata-rata untuk perusahaan yang menggunakan metode FIFO sebesar 17,4212 sedangkan untuk kelompok perusahaan yang menggunakan metode rata-rata diperoleh rata-rata sebesar 0,3960 . Hal ini berarti bahwa pada perusahaan yang menggunakan metode FIFO menunjukkan variabilitas laba akuntansi yang lebih besar dibanding pada perusahaan yang menggunakan metode rata-rata.

\section{Tabel 6}

Statistik Deskriptif Variabilitas Harga Pokok Penjualan

\begin{tabular}{|l|l|l|l|l|l|}
\hline $\begin{array}{l}\text { Meto } \\
\text { de }\end{array}$ & N & $\begin{array}{l}\text { Rata } \\
- \\
\text { Rata }\end{array}$ & $\begin{array}{l}\text { Std. } \\
\text { Devi } \\
\text { asi }\end{array}$ & $\begin{array}{l}\text { Minim } \\
\text { um }\end{array}$ & $\begin{array}{l}\text { Maksim } \\
\text { um }\end{array}$ \\
\hline FIFO & $\begin{array}{l}6 \\
0\end{array}$ & $\begin{array}{l}0,14 \\
10\end{array}$ & $\begin{array}{l}0,20 \\
20\end{array}$ & 0,01 & 1,14 \\
\hline Rata & 2 & 0,14 & 0,19 & 0,00 & 1,41 \\
\hline Rata & $\begin{array}{l}11 \\
0\end{array}$ & 24 & & \\
\hline Total & 3 & 0,14 & 0,19 & 0,00 & 1,41 \\
& 0 & 11 & 40 & & \\
& 0 & & & & \\
\hline
\end{tabular}

Sumber : Data sekunder yang diolah

\begin{tabular}{|l|l|l|l|}
\hline Step & Chi-square & df & Sig. \\
\hline 1 & 5,064 & 8 &, 751 \\
\hline
\end{tabular}

Tabel $\quad 4.8 \quad$ menunjukkan gambaran variabilitas harga pokok penjualan selama tahun 2009-2014 diperoleh rata-rata untuk perusahaan yang menggunakan metode rata-rata sebesar 0,1411 sedangkan untuk ${ }^{3}$ kelompok perusahaan yang menggunakan metode FIFO diperoleh rata-rata sebesar 0,1410. Hal ini berarti bahwa pada perusahaan yang menggunakan metode rata-rata menunjukkan variabilitas harga pokok penjualan yang lebih besar dibanding pada perusahaan yang menggunakan metode FIFO.

Analisis Regresi Logistik

\section{a. Menilai Kelayakan Model Regresi (Goodness of Fit)}

Tabel tersebut menunjukkan hasil pengujian, nilai chi-square sebesar 5,064 dengan signifikansi sebesar 0,751 . Dengan nilai signifikansi pada uji Hosmer and LameshowTest sebesar 0,751. Oleh karena nilai signifikansi lebih besar dari $\alpha=0,05$, maka model data penelitian pengaruh variabilitas persediaan, ukuran perusahaan, intensitas persediaan, variabilitas laba akuntansi, variabilitas harga pokok penjualan dan struktur kepemilikan terhadap pemilihan metode akuntansi persediaan dapat dikatakan fit dan baik sehingga layak dilakukan pengujian selanjutnya.

\section{b. Menilai Keseluruhan Model (Overall Model Fit)}

Tabel 8

Omnibus Tests of Model Coefficients

\begin{tabular}{|r|l|l|l|}
\hline & $\begin{array}{l}\text { Chi- } \\
\text { square }\end{array}$ & df & Sig. \\
\hline Step 1 Step & 91,023 & 6 &, 000 \\
Block & 91,023 & 6 &, 000 \\
Model & 91,023 & 6 &, 000 \\
\hline
\end{tabular}


Pengujian kemaknaan prediktor secara bersama-sama dalam regresi logistik menunjukan nilai chi-square sebesar 91,023 dengan signifikansi sebesar 0,00 . Nilai signifikansi yang lebih kecil dari 0,05 menunjukan adanya pengaruh yang bermakna dari kelima variabel dalam menjelaskan variabel pemilihan metode penilaian persediaan.

Besarnya nilai koefisien determinasi pada model regresi logistik ditunjukkan dengan nilai Nagelkerke $R$ Square. Selanjutnya, variabilitas antara variabel terikat dengan variabel bebas dapat dilihat pada tabel di bawah ini :

\section{Tabel 9}

Model Summary

\begin{tabular}{|l|l|lr|l|}
\hline & $-2 \quad$ Log & Cox \& & Nagelker \\
Ste & likelihoo & Snell & $R$ & ker R \\
$p$ & $d$ & Square & Square \\
\hline 1 & $209,219^{a}$ &, 262 &, 414 \\
\hline
\end{tabular}

a. Estimation terminated at iteration number 20 because maximum iterations has been reached. Final solution cannot be found.

Dari hasil penelitian terlihat angka koefisien determinasi pada pengujian Cox and Snell Square sebesar 0,262 dan nilai Nagelkerke R Square sebesar 0,414, yang berarti variabel variabilitas persediaan, ukuran perusahaan, intensitas persediaan, variabilitas laba akuntansi, variabilitas harga pokok penjualan dan struktur kepemilikan dapat menjelaskan variabel pemilihan metode penilaian persediaan adalah sebesar $41,4 \%$, sedangkan $68,6 \%$ lainnya dijelaskan oleh variabel lain.

\section{b. Menguji Koefisien Regresi}

Setelah mendapatkan model regresi logistik yang fit yang tidak memerlukan modifikasi model, maka pengujian hipotesis dapat dilakukan. Hasil pengujian hipotesis dilakukan dengan menggunakan uji secara parsial. Pengujian kemaknaan prediktor secara parsial dilakukan dengan menggunakan uji Wald dan dengan pendekatan chi-square diperoleh sebagai berikut:

Tabel 4.13

Hasil Analisis Regresi Logistik

\begin{tabular}{|ll|l|l|l|l|l|l|}
\hline \multicolumn{7}{|c|}{ Variables in the Equation } \\
\hline & & B & S.E. & Wald & df & Sig. & $\begin{array}{l}\text { Exp( } \\
\text { B) }\end{array}$ \\
\hline $1^{\text {a }}$. & VP & 1,011 &, 441 & 5,260 & 1 &, 022 & 2,749 \\
& UP &, 000 &, 000 & 16,68 & 1 &, 000 & 1,000 \\
& IP &, 000 &, 000 &, 003 & 1 &, 959 & 1,000 \\
& VLA &, 002 &, 003 &, 679 & 1 &, 410 & 1,002 \\
VHPP &,- 301 &, 856 &, 123 & 1 &, 725 &, 740 \\
SK & - & 4553, &, 000 & 1 &, 996 &, 000 \\
& 20,53 & 374 & & & & \\
Const &,- 357 &, 296 & 1,459 & 1 &, 227 &, 700 \\
ant & &
\end{tabular}

a. Variable(s) entered on step 1: VP, UP, IP, VLA, VHPP, SK. Sumber : Data sekunder yang diolah

Hasil pengujian terhadap koefisien regresi menghasilkan model sebagai berikut :

$Y=-0,357+1,011 \mathrm{VP}+0,000 u P+$ $0,000 \mathrm{IP}+0,002 \mathrm{VLA}-0,301 \mathrm{VHPP}-$ 20,539 sk

\section{c. Menguji Hipotesis \\ H1 : Pengaruh Variabilitas \\ Persediaan Terhadap Pemilihan Metode Penilaian Persediaan}

Berdasarkan

hasil

pengujiandiperoleh nilai wald variabel variabilitas persediaan sebesar 5,260dengan nilai signifikasi sebesar 0,022 . Oleh karena nilai signifikansi lebih kecil dari 0,05, maka hipotesis pertama diterima. Hal ini berarti bahwa variabel variabilitas persediaan berpengaruh signifikan terhadap pemilihan metode penilaian persediaan. Hasil penelitian ini tidak konsisten dengan penelitian yang di teliti oleh Srimonah (2011). 
Perusahaan yang memiliki tingkat variabilitas tinggi, maka akan menghasilkan variasi laba yang tinggi pula. Perusahaan yang menggunakan metode FIFO akan menghasilkan variasi persediaan yang tinggi sedangkan perusahaan yang perusahaan yang menggunakan metode rata-rata menghasilkan variasi persediaan yang kecil. Besar kecilnya variasi persediaan akan mempengaruhi laba yang dihasilkan perusahaan. Oleh sebab itu, tingkat variasi laba yang tinggi cenderung mendorong perusahaan untuk memilih metode persediaan FIFO untuk dapat meningkatkan laba perusahaan. Begitupun sebaliknya, dalam kondisi ekonomi tertentu perusahaan yang memiliki variabilitas yang rendah, cenderung akan menghasilkan variabilitas persediaan yang rendah pula. Perusahaan terdorong untuk menggunakan metode persediaan rata-rata untuk memperkecil laba, sehingga dapat melakukan penghematan pajak yang dibayarkan oleh perusahaan.

\section{H2 : Pengaruh Ukuran Perusahaan Terhadap Pemilihan Metode Penilaian Persediaan}

Berdasarkan hasil pengujian diperoleh nilai wald variabel ukuran perusahaan sebesar 16,681dengan nilai signifikasi sebesar 0,000 . Oleh karena nilai signifikansi lebih kecil dari 0,05, maka hipotesis kedua diterima. Hal ini berarti bahwa variabel ukuran perusahaan berpengaruh signifikan terhadap pemilihan metode penilaian persediaan. Hasil penelitian ini konsisten dengan penelitian yang diteliti oleh Kukuh (2012), Seyla (2013) dan Brian (2014).

Kenyataan yang dihasilkan dalam penelitian ini adalah perusahaan besar cenderung untuk memilih menggunakan metode penilaian persediaan rata-rata diabndingkan dengan menggunakan metode persediaan FIFO. Hal ini sesuai dengan teori yang ada dimana perusahaan besar cenderung untuk memilih metode rata-rata yang dapat menurunkan laba, dengan melaporkan laba yang kecil perusahaan besar akan mendapatkan suatu penghematan pajak. Perusahaan-perusahaan besar tidak terlalu tertarik menggunakan metode FIFO yang melaporkan laba yang tinggi. Sedangkan perusahaan kecil lebih memilih menggunakan metode penilaian persediaan FIFO agar dapat meningkatkan laba, sehingga akan memberikan gambaran kinerja yang bagus, dengan demikian kemungkinan mendapatkan dana dari bank semakin besar dan menarik investor untuk menanamkan modal.

\section{H3 : Pengaruh Intensitas Persediaan Terhadap Pemilihan Metode Akuntansi Persediaan}

Berdasarkan hasil pengujian diperoleh nilai wald variabel intensitas persediaan sebesar 0,003 dengan nilai signifikasi sebesar 0,959 . Oleh karena nilai signifikansi lebih besar dari 0,05, maka hipotesis ketiga ditolak. Dengan kata lain dapat dikatakan bahwa variabel intensitas persediaan tidak berpengaruh signifikan terhadap pemilihan metode penilaian persediaan. Hasil penelitian ini tidak konsisten dengan penelitian yang diteliti oleh Kukuh (2012).

Intensitas persediaan tidak berpengaruh terhadap pemilihan metode penilaian persediaan dikarenakan tidak semua perusahaan yang memiliki tingkat intensitas tinggi menghasilkan efektifitas dan efisiensi dalam kegiatan operasionalnya, sebab lain yang dapat memungkinkan tingkat intensitas yang tinggi dapat terjadi adalah kasus yang terjadi pada perusahaan yang mengalami 
kadaluarsa pada produknya. Hal ini cenderung menimbulkan kerugian terhadap perusahaan.

\section{H4 : Pengaruh Variabilitas Laba Akuntansi Terhadap Pemilihan Metode Akuntansi Persediaan}

Berdasarkan hasil pengujian diperoleh nilai wald variabel variabilitas laba akuntansi sebesar 0,679 dengan nilai signifikasi sebesar 0,470 . Oleh karena nilai signifikansi lebih besar dari 0,05, maka hipotesis keempat ditolak. Dengan kata lain dapat dikatakan bahwa variabel variabilitas laba akuntansi tidak berpengaruh signifikan terhadap pemilihan metode penilaian persediaan. Hasil penelitian ini konsisten dengan penelitian yang diteliti oleh Sangadah (2014), Brian (2014) dan Herlin (2011).

Variabilitas laba akuntansi tidak berpengaruh signifikan terhadap pemilihan metode penilaian persediaan barang dikarenakan variabel laba akuntasi merupakan laba sebelum pajak, sedangkan salah satu pertimbangan dalam pemilihan metode penilaian persediaan adalah hipotesis pajak. Jadi laba sebelum pajak kurang dapat menggambarkan kondisi operasional perusahaan karena juga dipengaruhi oleh faktor eksternal yang telah memasukan keuntungan atau kerugian selisih kurs atau laba akuntansi merupakan salah satu tujuan perusahaan yang diusahakan unutk memaksimalkan dengan metode FIFO saat terjadi inflasi. Namun demikian krisis finansial global yang terjadi menyebabkan banyaknya perusahaan merugi. Kerugian selisih kurs dapat menyebabkan laba akuntansi masuk ke dalam unsur non operasional.

H5 : Pengaruh Variabilitas Harga Pokok Penjualan Terhadap Pemilihan Metode Akuntansi Persediaan
Berdasarkan hasil pengujian diperoleh nilai wald variabel harga pokok penjualan sebesar 0,123 dengan nilai signifikasi sebesar 0,725 . Oleh karena nilai signifikansi lebih besar dari 0,05, maka hipotesis kelima ditolak. Dengan kata lain dapat dikatakan bahwa variabel harga pokok penjualan tidak berpengaruh signifikan terhadap pemilihan metode penilaian persediaan. Hasil penelitian ini tidak konsisten dengan penelitian yang diteliti oleh Thresya (2013).

Hal ini mungkin dikarenakan terjadinya inflasi pada penelitian ini yaitu di tahun 2010. Dimana dengan adanya kenaikan tingkat inflasi, harga pokok penjualan akan mengalami kenaikan sehingga dapat mempengaruhi nilai pada harga pokok penjualan di laporan keuangan, yang juga akan mempengaruhi laba yang akan diperoleh oleh perusahaan. Secara umum perusahaan menginginkan pajak yang rendah karena pajaknya yang rendah, sehingga ketika terjadi inflasi perusahaan akan tetap menggunakan metode rata-rata yang menunjukan harga pokok penjualan yang tinggi dengan laba yang rendah dibandingkan dengan menggunakan metode penilaian persediaan FIFO.

\section{H6 : Pengaruh Struktur Kepemilikan Terhadap Pemilihan Metode Akuntansi Persediaan}

Berdasarkan hasil pengujiandiperoleh nilai wald variabel struktur kepemilikan sebesar 0,000 dengan nilai signifikasi sebesar 0,996. Oleh karena nilai signifikansi lebih besar dari 0,05, maka hipotesis keenam ditolak. Dengan kata lain dapat dikatakan bahwa variabel harga pokok penjualan tidak berpengaruh signifikan terhadap pemilihan metode penilaian persediaan. Hasil penelitian ini tidak konsisten dengan penelitian 
yang diteliti oleh Brian (2014) dan konsisten dengan penelitian yang dilakukan oleh Srimonah (2011).

Kepentingan manajer secara individu tidak nampak sebagai upaya untuk menentukan salah satu metode penilaian persediaan. Hal ini mengesankan, manajer tidak berusaha memilih metode pencatatan persediaannya untuk meningkatkan kemakmuran mereka. Biasanya manajer memilih menggunakan metode FIFO agar memperoleh laba yang besar sehingga kompensasi yang diterima juga semakin besar. Akan tetapi dalam penelitian ini tidak menunjukan hasil adanya upaya manajer tersebut

\section{KESIMPULAN}

Dari hasil pengujian diketahui bahwa variabel variabilitas persediaan dan ukuran perusahaan berpengaruh signifikan terhadap pemilihan metode penilaian persediaan. Sedangkan variabel intensitas persediaan, variabilitas laba akuntansi, variabilitas harga pokok penjualan dan struktur kepemilikan tidak berpengaruh signifikan terhadap pemilihan metode penilaian persediaan.

\section{REFERENCES}

Baridwan, Zaki. 1995. Intermediate Accounting. Edisi Ketujuh. Yogyakarta : BPFE-YOGYAKARTA Brian Syailendra, Raharja. 2014. "Analisis Faktor-Faktor yang Berpengaruh Terhadap Pemilihan Metode Penilaian Persediaan (Studi Kasus pada Perusahaan Dagang dan Manufaktur yang terdaftar di BEI tahun 2008-2012)". Jurnal Universitas Diponegoro. Volume 3, nomor 2, halaman 1.

Erlina, 2011. Metodologi Penelitian. Medan: USU Pers.

Ghozali, Imam. 2012. Aplikasi Analisis Multivariate dengan Program IBM
SPSS 20. Semarang : Universitas Diponegoro.

Herlin Tundjung, Cecilia Pratiwi. 2011. "Pengaruh Beberapa Variabel Terhadap Pemilihan Metode Penilaian Persediaan pada Perusahaan Manufaktur". Jurnal Universitas Tarumanegara.

Iskandar, Thresya. 2013. "Pengaruh Ukuran Perusahaan, Variabilitas Persediaan, Variabilitas Harga Pokok Penjualan, Laba Sebelum Pajak dan Financial Leverage Terhadap Metode Penilaian Persediaan di Perusahaan Manufaktur yang Terdaftar di BEI tahun 2010-2012". Jurnal Fakultas Ekonomi Universitas Sumatera Utara.

Jay M, Smith, K. Fred Skousen. 1989. Akuntansi Intermediate Volume Komperehensif Jilid I. Jakarta : Erlangga

Kieso, Donald E., Jerry J. Weygandt dan Terry D. Warfield, . Akuntansi Intermediate.Edisi Kesepuluh. Jakarta : Erlangga.

Kukuh, Heri. 2014. "Analisis FaktorFaktor yang Berpengaruh Terhadap Metode Akuntansi Persediaan". Jurnal Universitas Diponegoro.

Mukhlasin, 2001. "Analisis Pemilihan Metode Akuntansi Persediaan dan Dampaknya Terhadap Earning Price". Jurnal Universitas Diponegoro, Semarang.

Restu Maharani, 2013. "Pengaruh Ukuran Perusahaan, Margin Laba Kotor dan Perputaran Persediaan Terhadap Pemilihan Metode Penilaian Persediaan pada Perusahaan Manufaktur Sektor Industri Barang Konsumsi yang terdaftar di BEI periode 2009-2013". Jurnal Fakultas Ekonomi Universita Maritim Raja Ali Aji.

Skousen, Stice. 2004. Intermediate Accounting.Edisi Kelima Belas. Jakarta : Salemba Empat. 
Seyla Sangeroki. 2013. "Ukuran Perusahaan dan Margin Laba Kotor Terhadap Metode Penilaian Persediaan di Perusahaan Manufaktur". Jurnal EMBA, Vol 1 No 3.

Siti Sangadah, Kusmuriyanto. 2014. "Analisis Pemilihan Metode Akuntansi Persediaan pada Perusahaan Manufaktur". ISSN 22526765.

Srimonah, Ardiani, 2011. "Analisis FaktorFaktor yang Mempengaruhi Pemilihan Metode Penilaian Persediaan". Jurnal Fakultas Ekonomi Universitas Semarang.

Taqwa, Salma, 2001. "Faktor-Faktor yang Mempengaruh Pemelihan Metode Akuntansi Persediaan pada Perusahaan Manufaktur di BEJ". Tesis Universitas Diponrgoro, Semarang.

www.bei.co.id www.google.com www.idx.com www.sahamok.com 